\title{
RAPD-PCR OF TRICHODERMA ISOLATES AND IN VITRO ANTAGONISM AGAINST FUSARIUM WILT PATHOGENS OF PSIDIUM GUAJAVA L.
}

\author{
Vijai Kumar Gupta ${ }^{1}$, Ashok Kumar Misra ${ }^{2 *}$, Arti Gupta ${ }^{3}$, \\ Brajesh Kumar Pandey², Rajarshi Kumar Gaur ${ }^{1}$ \\ ${ }^{1}$ Department of Biotechnology, FASC, MITS University, Lakshmangarh-332311, Sikar, Rajasthan, India \\ ${ }^{2}$ Molecular Plant Pathology Lab., CISH, Lucknow-227 017, India \\ ${ }^{3}$ Mahatma Jyotiba Phule Rohilkhand University, Bareilly, UP, India
}

Received: May 20, 2009

Accepted: April 22, 2010

\begin{abstract}
The paper concerns randomly amplified polymorphic DNA RAPD-PCR analysis of seven Trichoderma species isolates and their in vitro antagonism against wilt pathogens of Psidium guajava L. viz. Fusarium oxysporum f. sp. psidii (F. o. f. sp. psidii) and Fusarium solani. Out of 10 RAPD oligonucleotides (OPA 1-OPA 10) tested, seven markers OPA 1, 3, 5, 7, 8, 9 and 10 efficiently differentiated the isolates of Trichoderma and showed reproducible banding patterns. A total of 248 bands were obtained from these markers along with a $61.84 \%$ per cent similarity among the seven isolates of Trichoderma. From the seven isolates of Trichoderma, isolates T. harzianum, T. virens and T. viride were evaluated for in vitro efficacy against $F$. o. f. sp. psidii and F. solani. Per cent inhibition was maximum by direct use of Trichoderma spp. in dual cultures against both pathogens, F. o. f. sp. psidii and F. solani. Two species, T. virens and T. viride were superior in inhibiting the growth of both Fusarium spp. Fusarium isolates showed intra species variability.
\end{abstract}

Key words: Trichoderma spp., RAPD-PCR, antagonism, Psidium guajava L., Fusarium oxysporum f. sp. psidii, Fusarium solani

\section{INTRODUCTION}

Guava (Psidium guajava L.) is an important fruit crop of subtropical countries. In India, it is grown in almost all of the states. Wilt is the most destructive disease of guava and causes a $5-60 \%$ loss in guava production in India. Various pathogens are reported to cause wilt in guava, but Fusarium oxysporum f. sp. psidii (F.o. f. sp. psidii) and F. solani are more widely reported as causal agents of the disease (Prasad et al. 1952; Misra 2006).

Advances in molecular biology techniques have provided the basis for uncovering a virtually unlimited number of DNA markers. The utility of DNA-based markers is generally determined by the technology that is used to reveal DNA-based polymorphism. The polymerase chain reaction (PCR) technique has created new ways of revealing DNA polymorphisms among closely related genotypes with high sensitivity, via a fast and easy-to-perform protocol. Zimand et al. (1994) used RAPD markers obtained from 9 arbitrary primers to distinguish strains of Trichoderma. Ten of the strains identified as T. harzianum exhibited similarities, and it was possible to distinguish the isolate T-39, used commercially as a biocontrol agent for Botrytis cinerea. For efficient taxonomic identification of Trichoderma spp., Fujimori and Okuda (1993) examined 74 strains by RAPD profiles and the results were consistent with the morphological, physiological and ecological data, which suggested that the technique can aid to eliminate strains duplicated in a program for microbial selection. Using RAPD Schlick et al. (1994) analyzed strains of T. harzianum and mutants induced by gamma radiation originated from a wild isolate, The analysis verified that with RAPD it was possible to differentiate all the mutant strains for at least one primer, concluding that the method was valuable for identification and fast differentiation of strains.

The disease is soil-borne and difficult to control by chemicals. The effect of chemicals is also hazardous for the soil and environment. This can be seen when after application and after the effect of the chemicals diminishes, pathogens become more virulent and aggressive (Misra and Pandey 1999). Hence, control of soil borne diseases by the biocontrol method is the best solution. Bioagents multiply in the soil, if proper moisture and organic matter are maintained. Biocontrol is a dynamic process and the frequent application of bioagents is not required. Trichoderma sp. has shown its effectiveness towards the control of wilt pathogens of guava (Misra 2006). Culture filtrate and volatile compounds released by these bioagents have also been found effective against different pathogens (Dennis and Webster 1971; Maththeis and Roberts 1992; Tapwal et al. 2004; Eziashi et al. 2006). 
The aim of the present investigation was to characterize Trichoderma spp. isolates using PCR-fingerprinting with RAPD primers (RAPD-PCR method) and to evaluate the ability of Trichoderma spp. isolates to suppress the growth of Fusarium wilt pathogens of Psidium guajava by in vitro.

\section{MATERIALS AND METHODS}

\section{Isolation of bioagents}

Seven isolates of Trichoderma spp. were obtained from guava fields. The guava fields which were in different locations (Table 1). These isolates were identified based on taxonomic keys (Raper and Thom 1949; Rifai 1969), pure cultured, and maintained on potato dextrose agar (PDA, Hi-Media), then analyzed for genetic variability. Finally three species isolates of Trichoderma obtained from guava field soil, T. harzianum (Tri 1), T. virens (Tri 2) and T. viride (Tri 7) were subjected to in vitro bio-control assay.

\section{Genetic analysis}

\section{DNA extraction}

Pure cultures of the Trichoderma isolates were maintained on PDA slants and incubated at $28 \pm 2^{\circ} \mathrm{C}$ for 6 days under controlled temperature. Mycelia were aseptically transferred to flasks of potato-dextrose broth (PDB, HiMedia) and incubated for 5 days at $28 \pm 2^{\circ} \mathrm{C}$ without shaking. The mycelia were filtered from the liquid medium and total DNA was extracted according to the protocol of Abd-Elsalam et al. (2003).

\section{RAPD-primers}

Ten oligodecamers OPA 01-5' CAGGCCCTTC 3'; OPA 02-5' TGCCGAGCTG 3'; OPA 03-5' AGTCAGCCAC 3'; OPA 04-5' AATCGGGCTG3'; OPA 05-5' AGGGGTCTTG3'; OPA 06-5' GCTCCCTGAC 3'; OPA 07-5' GAAACGGGTG 3'; OPA 08-5' GTGACGTAGG 3'; OPA 09-5' GGGTAACGCC 3'; OPA 10-5' GTGATCGCAG 3' (Life Technologies, India) were used for RAPD marker studies.

\section{Reactions and conditions of RAPD-PCR}

RAPD-PCR reaction was done in Eppendorf Master Cycler in $25 \mu$ reaction volume containing $25 \mathrm{ng}$ genomic DNA, $0.4 \mu \mathrm{l}$ (5 pmole) primer, $1.5 \mu \mathrm{l}$ dNTPs ( $25 \mathrm{mM}), 3 \mu \mathrm{l}$ of $10 \mathrm{X}$ assay buffer with $\mathrm{MgCl}_{2}(15 \mathrm{mM}), 0.5 \mu \mathrm{l}(3 \mathrm{U} / \mu \mathrm{l})$ of Taq DNA polymerase (Bangalore Genei Pvt. Ltd.). The reaction profile was as follows: denaturation for $5 \mathrm{~min}$ at $94^{\circ} \mathrm{C}$ followed by 35 cycles of $1 \mathrm{~min}$ each at $94^{\circ} \mathrm{C}$ and $35^{\circ} \mathrm{C}$, followed by $2 \mathrm{~min}$ at $72^{\circ} \mathrm{C}$, and a final extension for $5 \mathrm{~min}$ at $72^{\circ} \mathrm{C}$. PCR products were resolved by horizontal electrophoresis using agarose gel (1.2\%) with TAE buffer (1\%) containing ethidium bromide.

\section{Cluster analysis}

The genetic similarity of isolates was assessed, based on RAPD data, using Jaccard's coefficient (Jaccard 1908). The data was subsequently used to construct a dendrogram with the unweighted pair group method of arithmetical averages (UPGMA) algorithm, as described by Sneath and Sokal (1973) using the NTSYS-software (Rohlf 1998).

\section{In vitro biocontrol assay}

\section{Isolation of pathogens}

Five isolates each of F. o. f. sp. psidii (Fop) and F. solani (Fs) isolated from wilted guava roots from different guava growing areas of India were used in the present study (Table 2). These isolates were subcultured on potato dextrose agar (PDA, Hi-Media) and incubated at $28 \pm 1^{\circ} \mathrm{C}$ for 6 days. The morphological and cultural characterizations of the cultures grown on PDA were studied and compared with those mentioned by Booth (1971). The reference pure culture of the fungus was also sent to the Indian Type Culture Collection (ITCC), Division of Mycology and Plant Pathology, I.A.R.I., New Delhi-110 012 for the identification of: F. solani [ITCC No. 5208 (F20) and 5212 (F15)] and F. oxysporum f. sp. psidii [MTCC No. 3326 (F24) and 3327 (F30)] was sent to the Microbial Type Culture Collection for identification. These identified cultures were used as reference species. Pure cultures of the isolates were maintained on PDA slants under controlled temperature at $28 \pm 1^{\circ} \mathrm{C}$. Pathogenicity of these isolates was also confirmed.

Table 1. The origin of Trichoderma spp. isolates used in the present study

\begin{tabular}{|c|l|l|c|l|}
\hline No. & \multicolumn{1}{|c|}{ Source } & \multicolumn{1}{|c|}{ Location } & $\begin{array}{c}\text { Cultural } \\
\text { No. }\end{array}$ & \multicolumn{1}{|c|}{ Bio-agent } \\
\hline 1. & Rhizosphere of wilted guava plant & Pinjour garden, Punjab, India & Tri 1 & T. harzianum \\
\hline 2. & Rhizosphere of wilted guava plant & Allahabd, Utter Pradesh, India & Tri 2 & T. virens \\
\hline 3. & Rhizosphere of wilted guava plant & PAU, Punjab, India & Tri 3 & T. harzianum \\
\hline 4. & Rhizosphere of wilted guava plant & Kausambi, Utter Pradesh, India & Tri 4 & T. virens \\
\hline 5. & Rhizosphere of wilted guava plant & Dharwad, Karnataka, India & Tri 5 & T. harzianum \\
\hline 6. & Rhizosphere of wilted guava plant & Dharwad, Karnataka, India & Tri 6 & T. viride \\
\hline 7. & Rhizosphere of wilted guava plant & $\begin{array}{l}\text { Rewa Agriculture College Rewa, Madhya } \\
\text { Pradesh, India }\end{array}$ & Tri 7 & T. viride \\
\hline
\end{tabular}


Table 2. The characteristics of Fusarium spp. isolates of guava used in the present study

\begin{tabular}{|c|c|c|c|c|c|c|c|c|c|c|c|}
\hline \multirow{3}{*}{$\begin{array}{l}\text { Isolate } \\
\text { No. }\end{array}$} & \multirow{3}{*}{ Location } & \multirow{3}{*}{$\begin{array}{c}\text { Disease } \\
\text { severity } \\
\text { level }\end{array}$} & \multirow{3}{*}{ Identification } & \multicolumn{4}{|c|}{ Spore Size $[\mu \mathrm{m}]$} & \multirow{2}{*}{\multicolumn{2}{|c|}{$\begin{array}{c}\text { Sporulation } \\
\text { Conidia }\end{array}$}} & \multirow{3}{*}{$\begin{array}{c}\text { Spore } \\
\text { septation } \\
\text { of Macro- } \\
\text { conidia }\end{array}$} & \multirow{3}{*}{$\begin{array}{c}\text { Colour of } \\
\text { released } \\
\text { metabolite in } \\
\text { the media }\end{array}$} \\
\hline & & & & \multicolumn{2}{|c|}{ macro } & \multicolumn{2}{|c|}{ micro } & & & & \\
\hline & & & & $\mathrm{L}$ & W & $\mathrm{L}$ & $\mathrm{W}$ & macro & micro & & \\
\hline \multicolumn{12}{|c|}{ F. oxysporum f. sp. psidii } \\
\hline F10 & Chandigarh & $50 \%$ & Booth, 1971 & 31.72 & 4.76 & 12.49 & 4.85 & +++ & + & $3-5$ & light brown \\
\hline F18 & Ranchi & $100 \%$ & Booth, 1971 & 44.82 & 4.51 & 10.05 & 4.96 & ++ & +++ & $5-7$ & brown \\
\hline F24 & Kanpur & $50 \%$ & MTCC 3326 & 38.61 & 5.12 & 13.73 & 4.69 & ++ & ++ & $5-7$ & pale yellow \\
\hline F30 & Unnao & $50 \%$ & MTCC 3327 & 39.50 & 6.87 & 9.61 & 8.32 & + & + & $5-7$ & pale yellow \\
\hline F38 & Rewa & $50 \%$ & Booth, 1971 & 40.88 & 6.18 & 9.56 & 5.48 & + & ++ & $4-5$ & dark yellow \\
\hline \multicolumn{12}{|c|}{ F. solani } \\
\hline F2 & West Bengal & $100 \%$ & Booth, 1971 & 35.54 & 10.09 & 18.16 & 8.98 & + & + & $3-4$ & violet \\
\hline F12 & Chandigarh & $50 \%$ & Booth, 1971 & 23.79 & 7.50 & 13.76 & 7.56 & ++ & + & $3-5$ & pinkish colour \\
\hline F15 & Ajmer & $100 \%$ & ITCC 5212 & 35.62 & 8.91 & 16.94 & 5.91 & + & ++ & $3-5$ & pinkish \\
\hline F20 & Puskar & $100 \%$ & ITCC 5208 & 36.08 & 10.35 & 14.39 & 6.70 & ++ & ++ & $3-5$ & pinkish \\
\hline F29 & Unnao & $100 \%$ & Booth, 1971 & 33.27 & 8.13 & 14.86 & 5.66 & +++ & + & $3-5$ & pink yellow \\
\hline
\end{tabular}

+ little sporulation; ++ moderate sporulation; +++ profuse sporulation

Inhibition of pathogenic fungi by bioagents using the dual culture technique

Inhibition of 5 isolates each of F. o. f. sp. psidii and F. solani were evaluated by 3 isolates of Trichoderma [T. harzianum (Tri 1)], T. virens (Tri 2) and T. viride (Tri 7) using the dual culture technique (Watts et al. 1988). Mycelial discs of $5 \mathrm{~mm}$ each of Fusarium sp. and all bioagents obtained from actively growing colonies were placed on the two halves of the solidified PDA plates. Plates were incubated at $28 \pm 1^{\circ} \mathrm{C}$ for 6 days and growth of Fusarium sp. was recorded. Percentage of inhibition was calculated. Mean PI value of four replicates per isolate was calculated (Grondona et al. 1997).

Determination of antifungal properties of culture filtrate of bioagents

Three isolates of Trichoderma spp. [T. harzianum (Tri 1)], T. virens (Tri 2) and T. viride (Tri 7) were separately inoculated into $100 \mathrm{ml}$ of potato dextrose broth per conical flask and incubated at $28 \pm 1^{\circ} \mathrm{C}$ for 6 days. After incubation for 6 days, the cultures were filtered through $0.22 \mathrm{~mm}$ Millipore filters. The aliquots $(2 \mathrm{ml})$, of these filtrates were mixed with $25 \mathrm{ml}$ of PDA at $45^{\circ} \mathrm{C}$. Petriplates were rotated gently so that the culture filtrate properly mixes in the medium. Mycelial discs (5 $\mathrm{mm}$ diameter) of the pathogens obtained from actively growing colonies were placed gently in the center of the PDA petriplates. The petriplates were incubated at $28 \pm 1^{\circ} \mathrm{C}$ for 6 days. The growth rate of the pathogens were recorded in 4 replicates by measuring the diameter of colonies. Per cent inhibition was calculated for each replicate (Hutchinson and Cowan 1972).

\section{Determination of the effect of the volatile compound}

The bottom part of petriplates containing solidified PDA media were inoculated in the center with $5 \mathrm{~mm}$ discs of each of the Fusarium sp. isolates and all the 3 bioagents (Trichoderma isolates) obtained from actively growing colonies. These plates were placed on each other so that the bottom parts of the plates contained bio-agents and the upper half of the plates contained pathogens. These inverted plates were sealed with parafilm and incubated at $28 \pm 1^{\circ} \mathrm{C}$ for 6 days. The radial growth of the pathogen was measured on the 6 th day. The volatile compounds released by bioagents were intended to affect the growth of pathogens. Per cent inhibition was calculated according to Tapwal et al. (2004).

\section{RESULTS}

\section{RAPD analysis}

Ten different (OPA 1 to OPA 10) random primers were tested with DNA samples of Trichoderma spp. isolates. Out of twenty RAPD markers tested OPA 01, 03, $05,09,11,15$ and 19 which were amplified in all isolates having a product size of $0.564 \mathrm{kbp}$ and $0.125 \mathrm{kbp}$ with OPA 01, $2.322 \mathrm{kbp}$ and $0.564 \mathrm{kbp}$ with OPA 03, $0.564 \mathrm{kbp}$ and $0.125 \mathrm{kbp}$ with OPA 05, $2.027 \mathrm{kbp}$ and $0.564 \mathrm{kbp}$ with OPA 09, $4.361 \mathrm{kbp}, 2.322 \mathrm{kbp}$ and $0.564 \mathrm{kbp}$ with OPA 11, $4.361 \mathrm{kbp}$ and $0.125 \mathrm{kbp}$ with OPA 15, $2.027 \mathrm{kbp}, 0.564$ $\mathrm{kbp}$ and $0.125 \mathrm{kbp}$ with OPA 19 respectively along with other polymorphic alleles (Fig. 1). The largest amplified RAPD product was $6.557 \mathrm{kbp}$ and the smallest was $0.125 \mathrm{kbp}$. The product of $0.564 \mathrm{kbp}$ was amplified with almost all RAPD markers tested. The number of scorable bands for corresponding primers ranged from 1 to 10 with an average of five bands. A total of 248 bands were scored against 7 isolates of the Trichoderma spp. A $4.66 \%$ polymorphism was also found in individual isolates but this polymorphism was not statistically significant ( $p>0.05$ ) among the samples. The average similarity per cent, based on amplified RAPD primers, was $61.84 \%$. A dendrogram constructed using the UPGMA method showed two major groups consisting of A) T. harzianum and $T$. virens isolates, and B) T. viride. It proved that $T$. harzianum and T. virens are genetically closely related species, with morphological similarity (Fig. 2). 
OPA 01

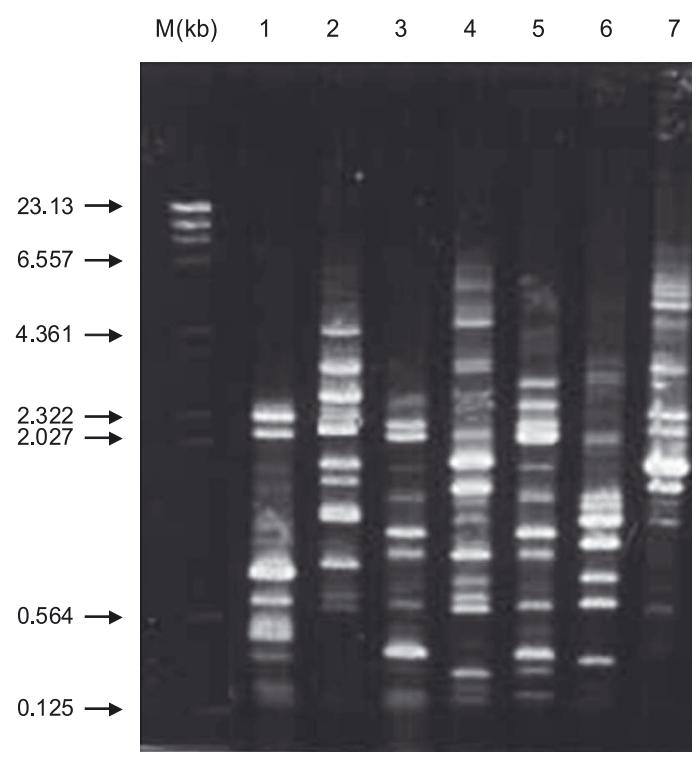

OPA 09

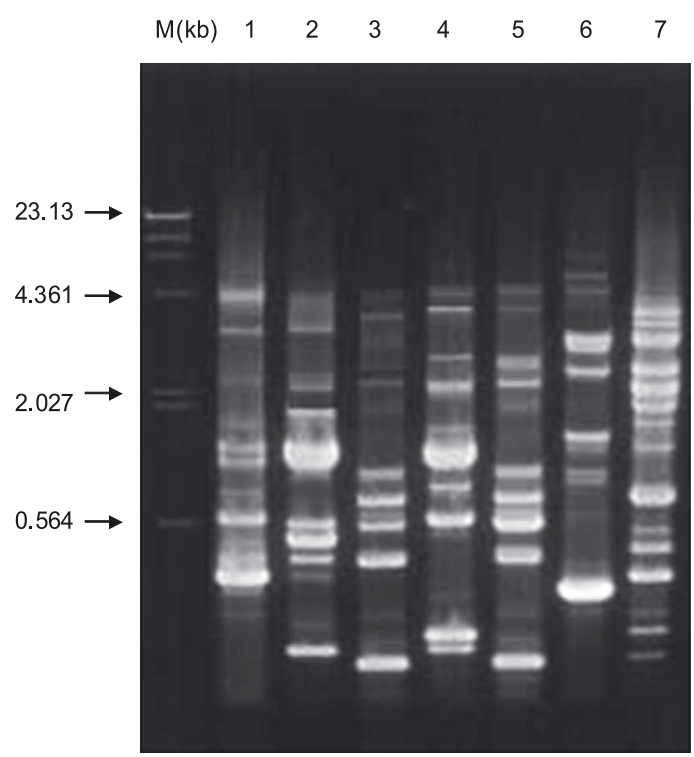

OPA 03

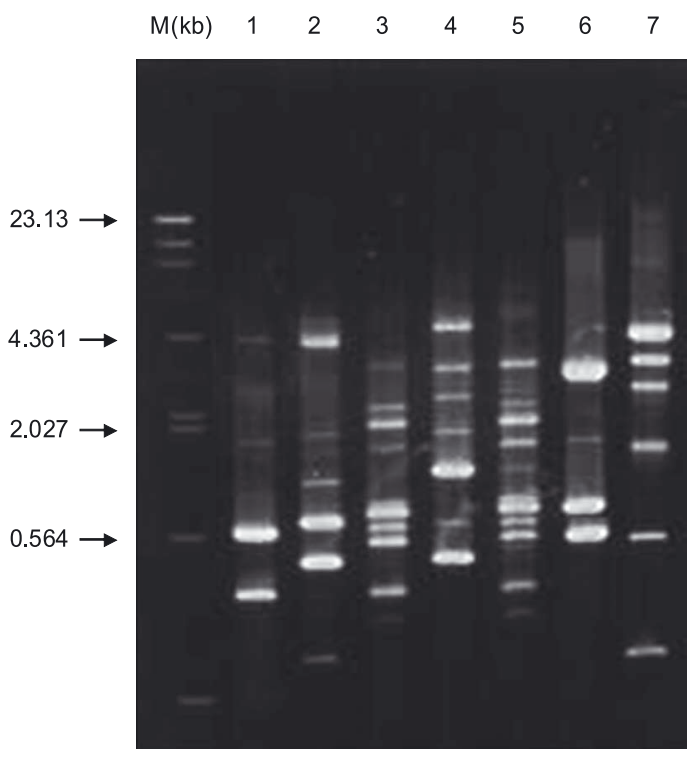

\section{OPA 10}

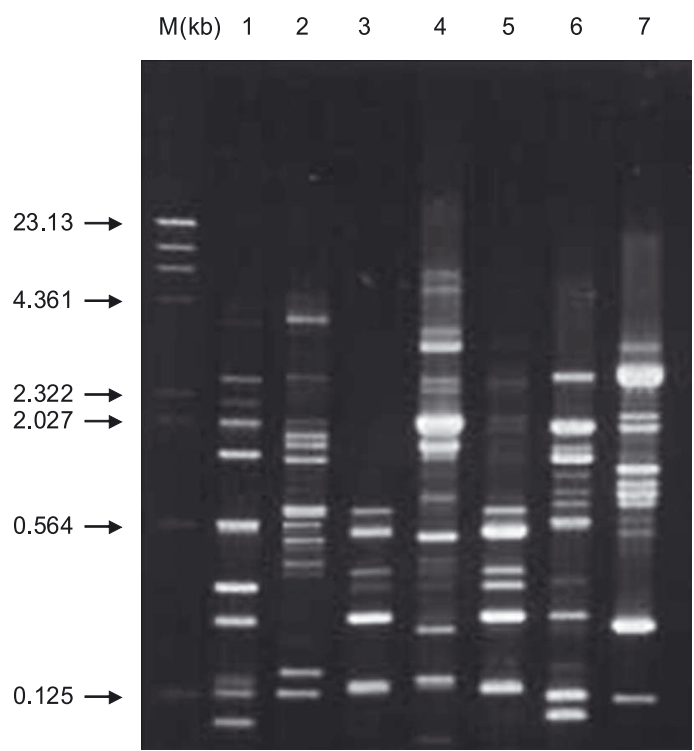

Fig. 1 Banding patterns of Trichoderma spp. isolates obtained using RAPD primers OPA 01, 03, 09 and OPA 10; lane 1-7= Trichoderma spp. Isolates $(1,3$ and $5=T$. harzianum; 2 and $4=T$. virens; 6 and $7=T$. viride $) \mathrm{M}$ - molecular weight size markers $(\lambda$ DNA treated by Hind III)

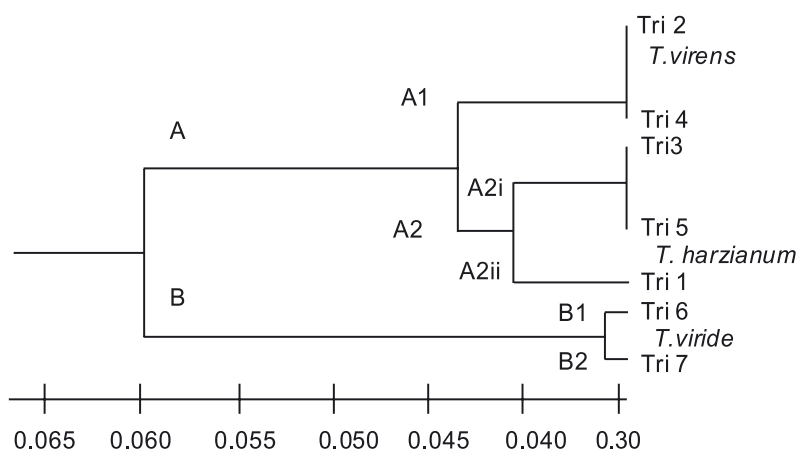

Fig. 2. Dendogram based on an allelic banding pattern obtained from RAPD markers 


\section{In vitro biocontrol assay}

When three species of Trichoderma i.e. T. harzianum (Tri 1), T. virens (Tri 2) and T. viride (Tri 7) were directly evaluated against F. o. f. sp. psidii and F. solani isolates, it was found that T. harzianum (Tri 1), T. virens (Tri 2) and T. viride (Tri 7) showed variable results against the different isolates of Fusarium oxysporum f. sp. psidii, while Tri 2 was slightly superior against $F$. solani isolates (Table 3 ).
Tri 7 isolate of $T$. viride was the best of all the isolates of both the Fusarium sp. (Table 3). In the case of the volatile compound Tri 2, it was superior for Fop isolates, and Tri 2 and Tri 7 were superior for Fs isolates (Table 3). In general, Tri 1 was less effective compared to Tri 2 and Tri 7; however, Tri 7 seemed to be better, compared to Tri 1 . The direct inhibition by culture was more effective than toxic metabolites released by isolates of Trichoderma spp. in culuture filtrate or action of volatile compound.

Table 3. In vitro evaluation of Trichoderma sp. (Tri) isolates, culture filtrate and volatile compound against F. oxysporum. f. sp. psidii (Fop) and F. solani (Fs) isolates causing Fuarium wilt of guava

\begin{tabular}{|c|c|c|c|c|c|c|c|}
\hline \multirow{2}{*}{$\begin{array}{l}\text { F. o. f. sp. psidii } \\
\text { isolates }\end{array}$} & \multicolumn{3}{|c|}{$\begin{array}{l}\text { Per cent inhibition of Fop } \\
\text { in presence of Tri isolates }\end{array}$} & \multirow{2}{*}{$\begin{array}{l}\text { F. solani } \\
(\mathrm{Fs}) \text { isolates }\end{array}$} & \multicolumn{3}{|c|}{$\begin{array}{c}\text { Per cent inhibition Fs } \\
\text { in presence of Tri isolates }\end{array}$} \\
\hline & $\begin{array}{l}\text { T. harzianum } \\
\text { (Tri 1) }\end{array}$ & $\begin{array}{l}\text { T. virens } \\
\text { (Tri 2) }\end{array}$ & $\begin{array}{l}\text { T. viride } \\
\text { (Tri 7) }\end{array}$ & & $\begin{array}{l}\text { T. harzianum } \\
\text { (Tri 1) }\end{array}$ & $\begin{array}{l}\text { T. virens } \\
\text { (Tri 2) }\end{array}$ & $\begin{array}{l}\text { T. viride } \\
\text { (Tri 7) }\end{array}$ \\
\hline \multicolumn{8}{|c|}{ Dual culture technique } \\
\hline Fop 10 & $63.44 \mathrm{~b}$ & $64.83 \mathrm{~b}$ & $68.96 a$ & Fs 2 & $58.39 \mathrm{c}$ & $67.15 a$ & $65.69 \mathrm{~b}$ \\
\hline Fop 18 & $61.81 \mathrm{c}$ & $67.36 a$ & $65.97 \mathrm{~b}$ & Fs 12 & $61.31 \mathrm{c}$ & $65.69 \mathrm{~b}$ & $65.69 \mathrm{~b}$ \\
\hline Fop 24 & $60.99 \mathrm{c}$ & $65.24 b$ & $65.24 \mathrm{~b}$ & Fs 15 & $59.57 \mathrm{~d}$ & $68.08 \mathrm{a}$ & $62.41 \mathrm{c}$ \\
\hline Fop 30 & $67.13 a$ & $65.73 b$ & $65.03 b$ & Fs 20 & $66.67 a$ & $62.41 \mathrm{~d}$ & $65.25 b$ \\
\hline Fop 38 & $66.19 a$ & 63.31c & $63.30 \mathrm{c}$ & Fs 29 & $64.34 \mathrm{~b}$ & $64.33 c$ & $67.14 a$ \\
\hline $\mathrm{CD}$ at $(\mathrm{p}=0.05)$ & 1.207 & 1.031 & 1.092 & $\mathrm{CD}$ at $(\mathrm{p}=0.05)$ & 0.940 & 1.136 & 0.928 \\
\hline \multicolumn{8}{|c|}{ Culture filtrate } \\
\hline Fop 10 & $35.85 a$ & 35.85 & $41.38 \mathrm{a}$ & Fs 2 & $32.11 b$ & $32.11 b$ & $40.14 a$ \\
\hline Fop 18 & $36.11 \mathrm{a}$ & 35.42 & $39.58 b$ & Fs 12 & $32.11 b$ & $31.38 b$ & $37.95 b$ \\
\hline Fop 24 & $34.04 b$ & 34.75 & $35.46 \mathrm{c}$ & Fs 15 & $34.75 a$ & $34.75 a$ & $36.88 \mathrm{c}$ \\
\hline Fop 30 & $34.96 \mathrm{~b}$ & 34.96 & $41.95 a$ & Fs 20 & $35.46 a$ & $34.75 a$ & $36.88 \mathrm{c}$ \\
\hline Fop 38 & $33.09 \mathrm{c}$ & 33.81 & $40.28 b$ & Fs 29 & $35.66 a$ & $35.66 a$ & $38.46 \mathrm{~b}$ \\
\hline $\mathrm{CD}$ at $(\mathrm{p}=0.05)$ & 1.414 & N.S. & 1.163 & $\mathrm{CD}$ at $(\mathrm{p}=0.05)$ & 0.929 & 0.917 & 1.053 \\
\hline \multicolumn{8}{|c|}{ Volatile compounds } \\
\hline Fop 10 & $28.27 a$ & $33.79 a$ & $28.96 \mathrm{~b}$ & Fs 2 & $26.27 \mathrm{~b}$ & $27.73 \mathrm{c}$ & $27.73 \mathrm{c}$ \\
\hline Fop 18 & $28.47 a$ & $32.64 \mathrm{~b}$ & $33.33 a$ & Fs 12 & $24.81 \mathrm{c}$ & $29.19 b$ & $27.73 c$ \\
\hline Fop 24 & $26.24 b$ & $31.91 b$ & $29.78 b$ & Fs 15 & $30.49 a$ & $29.78 b$ & $31.91 \mathrm{a}$ \\
\hline Fop 30 & $23.77 \mathrm{c}$ & $32.17 \mathrm{~b}$ & $32.86 a$ & Fs 20 & $25.53 c$ & $29.79 b$ & $30.49 \mathrm{~b}$ \\
\hline Fop 38 & $20.86 \mathrm{~d}$ & $30.21 \mathrm{c}$ & $27.34 \mathrm{c}$ & Fs 29 & $26.57 \mathrm{~b}$ & $32.86 a$ & $32.17 a$ \\
\hline $\mathrm{CD}$ at $(\mathrm{p}=0.05)$ & 1.098 & 1.022 & 1.150 & $\mathrm{CD}$ at $(\mathrm{p}=0.05)$ & 0.833 & 1.204 & 0.957 \\
\hline
\end{tabular}

$\mathrm{a}, \mathrm{b}, \mathrm{c}, \mathrm{d}$ - statistically analyzed at par values of the inhibition per cent

\section{DISCUSSION}

Molecular markers offer a means of constructing quality control tests that are essential throughout the developmental processes of these biocontrol agents. In the case of Trichoderma spp., the quality control test is being evaluated through the production of polymerase chain reaction (PCR) fingerprints by use of semi-random primers designed to primarily target intergenic, more variable areas in the genome (Dubey and Suresh 2006).

Arisan-Atac et al. (1995) studied 11 strains of T. viride, 2 strains of Hypocrea rufa and 9 other species of Trichoderma with relation to the RAPD profile and their ability for controlling Cryphonectria parasitica through pairing in vitro. Gomez et al. (1997) analyzed the RAPD profiles of strains of T. harzianum and classified them in different groups according to their capacity for control of plant pathogenic fungi. Muthumeenakshi et al. (1998) genetically characterized 15 strains of T. harzianum, aggressive for edible mushrooms in the United States and England, using RAPD. The strains were designated "T. harzianum group 4", presenting a high homogeneity degree. Comparison of the molecular data of group 4 with group 2 (the causal agent of the epidemic green mould in industrial mushrooms in England) indicated that the isolates of T. harzianum group 4 were different from that of group 2 . Most recently Gopal et al. (2008) investigated RAPD markers to estimate the genetic variation among 17 isolates of Trichoderma. and found them genetically similar showing a $91.8 \%$ polymorphism, which corroborates with the observations of our investigation. The RAPD technique 
was found to be advantageous over other molecular techniques for the genetic characterization of Trichoderma spp. due to the possibility of detecting DNA polymorphisms for very closely related strains (Bardakci 2001; Misra and Gupta 2009).

Many studies in the past have proved that Trichoderma spp. was a potential biocontrol agent of several soil borne pathogens (Chet and Inbar 1994). Kumar et al. (2007) tested three Trichoderma spp. i.e. T. virens, T. viride and T. harzianum against $F$. moniliforme var. subglutinans and found them effective. Isolates of Trichoderma spp. grew considerably faster than pathogenic Fusaria under the same conditions. The rapid growth gives Trichoderma an added advantage in competition for the space and nutrient with plant pathogenic fungi, even before it develops its arsenal of mycotoxins (Simon and Sivasithaparam 1988). Trichoderma was also found to control many crop diseases (Singh and Singh 2004; Kidwai et al. 2006). Our studies clearly indicated that Trichoderma spp. is a suitable antagonistic agent against $F$. o. f. sp. psidii and F. solani isolates.

Gupta et al. (2003) reported responses of different isolates of T. harzianum and T. viride against F. udum in vitro and in vivo, which supports our findings. The consortium of bioagents shall be further investigated. It was concluded that RAPD markers can easily designate and characterize Trichoderma spp. both at the isolate as well as at the species level. In the present investigation OPA 01, 03, 09 and OPA 10 RAPD primers were found to be informative in genetic variability studies for isolates of Trichoderma spp.

\section{ACKNOWLEDGEMENTS}

The authors wish to thank the Head of the Department of Crop-Protection and the Director of CISH for providing necessary research facilities.

\section{REFERENCES}

Abd-Elsalam K.A., Schnieder F., Guo J.R. 2003. A modified DNA extraction minipreparation protocol for Fusarium isolates. J. Rapid Methods Aut. Microbiol. 11: 75-79.

Arisan-Atac I., Heidenreich E., Kubicek C.P. 1995. Randomly amplified polymorphic DNA fingerprinting identifies subgroups of Trichoderma viride and other Trichoderma sp. capable of chestnut blight biocontrol. FEMS Microbiol. Lett. 126: 249-256.

Bardakci F. 2001. Random amplified polymorphic DNA (RAPD) markers. Turkey J. Biol. 25: 185-196.

Booth C. 1971. The Genus Fusarium. Commonwealth Mycological Institute, Kew, Surrey, England, 276 pp.

Chet I., Inbar J. 1994. Biological control of fungal pathogens. Appl. Biochem. Biotechnol. 48: 37-43.

Dennis C., Webster J. 1971. Antagonistic properties of species, groups of Trichoderma-II production of volatile antibiotics. Trans. Br. Mycol. Soc. 57: 41-48.

Dubey S.C., Suresh M. 2006. Randomly amplified polymorphic DNA markers for Trichoderma species and antagonism against Fusarium oxysporum f. sp. ciceris causing chickpea wilt. J. Phytopathol. 154: 663-669.
Eziashi E.J., Uma N.U., Adekunle A.A., Airede C.E. 2006. Effect of metabolites produced by Trichoderma species against Ceratocystis paradoxa in culture medium. African J. Biotechnol. 5: 703-706.

Fujimori F., Okuda T. 1993. Aplication of the random amplified polymorphic DNA using the polymerase chain reaction for efficient elimination of duplicate strains in microbial screening. J. Antibiot. 47: 173-182.

Gomez I., Chet I., Herreraestrela A. 1997. Genetic diversity and vegetative compatibility among Trichoderma harzianum isolates. Mol. Gen. Genet. 256: 127-135.

Gopal K., Sreenivasulua Y., Gopia V., Prasadbabua G., Kumarb T.B., Madhusudhana P., Ahemeda S.K., Palanivel S.G. 2008. Genetic variability and relationships among seventeen Trichoderma isolates to control dry root rot disease using RAPD markers. Z. Naturforsch. Sect. C. 63: 740-746.

Grondona I., Hermosa R., Tejada M., Gomis M.D., Mateos P.F., Bridge P.D., Monte E., García-acha I. 1997. Physiological and biochemical characterisation of Trichoderma harzianum, a biological control agent against soil-borne fungal plant pathogens. Appl. Environ. Microbiol. 63: 3189-3198.

Gupta R.P., Yadava B.C., Singh R.V., Rai O. 2003. Evaluation of Bioagents Against Fusarium wilt of Pigeonpea. p. 1-63. In: Proc. BS-57. National Symposium of Pulses for Crop-Diversification and Natural Resource Management, Kanpur, India, $148 \mathrm{pp}$.

Hutchinson S.A., Cowan M.E. 1972. Identification of biological effects of volatile metabolites from culture filtrate of Trichoderma harzianum. Trans. Br. Mycol. Soc. 59: 71-77.

Jaccard P. 1908. Nouvelles recherches sur la distribution florale. Bull. Soc. Vaudoise Sci. Nat. 44: 223-270.

Kidwai M.K., Vikas, Srivastava S., Singh H.B. 2006. Compatibility of Trichoderma harzianum to selected fungicide. J. EcoFriend. Agric. 1: 156-161.

Kumar P., Misra A.K., Pandey B.K. 2007. In vitro evaluation of Trichoderma spp. against vegetative mango malformation pathogen Fusarium moniliformae var. subglutinans. J. EcoFriend. Agric. 2: 187-189.

Maththeis J.P., Roberts R.G. 1992. Identification of geosmin as a volatile metabolite of Penicillium expansum. Appl. Environ. Microbiol. 58: 3170-3172.

Misra A.K., Pandey B.K. 1999. Pathogenicity and evaluation of fungicides against guava wilt pathogens. J. Mycol. Pl. Pathol. 29: 274-275.

Misra A.K. 2006. Wilt of guava-a disease of national importance. Indian Phytopathol. 59: 269-280.

Misra A.K., Gupta V.K. 2009. Trichoderma: biology, biotechnology and biodiversity. J. Eco-Friend. Agric. 4: 99-117.

Muthumeenakshi S., Brown A.E., Mills P.R. 1998. Genetic comparision of aggressive weed mould strains of Trichoderma harzianum from mushroom compost in North America and the British Isles. Mycol. Res. 4: 385-390.

Prasad N., Mehta P.R., Lal S.B. 1952. Fusarium wilt of guava (Psidium guajava L.) in Uttar Pradesh, India. Nature 169, p. 753.

Raper K.B., Thom C. 1949. A Manual of Penicillia. Williams and Wilkins, Baltimore, 691 pp.

Rifai M.A. 1969. Revision of the genus Trichoderma. Mycol. Pap. 116: 1-56.

Rohlf F.J. 1998 NTSYS-pc. Numerical Taxonomy and Multivariate Analysis System, Version 2.0. - Applied Biostatistics, New York, 37 pp. 
Schlick A., Kuhls K., Meyer W., Lieckfeldt E., Börner T., Messner K. 1994. Fingerprinting reveals gamma-ray induced mutatı tions in fungal DNA: implications for identification of patent strains of Trichoderma harzianum. Curr. Genet. 26: 74-78.

Simon C., Sivasithaparam M. 1988. Interaction among Gaeumannomyces graminum var. tritci, Trichoderma koningii and soil bacteria. Can. J. Microbiol. 34: 871-876

Singh A., Singh H.B. 2004. Control of color rot in mint (Mentha sp.) caused by Sclerotium rolfsii using biological mean. Curr. Sci. 87: 362-366.

Sneath P.H.A., Sokal R.R. 1973. Numerical Taxonomy. Freeman, San Francisco, 513 pp.

Tapwal A., Sharma Y.P., Lakhanpal T.N. 2004. Effect of volatile compound released by Gliocladium virens and Trichoderma spp. on growth of Alternaria mellea. J. Mycol. Pl. Pathol. 34: 308-310.

Watts S., Dahiya J., Chaudhary K. 1988. Isolation and characterization of new antifungal metabolite of Trichoderma reseii. Plant Soil 107: 81-84.

Zimand G., Valinsky L., Elad Y., Chet I., Manulis S. 1994. Use of the RAPD procedure for the identification of Trichoderma strains. Mycol. Res. 98: 531-534.

\section{POLISH SUMMARY}

RAPD-PCR IZOLATÓW GRZYBA

TRICHODERMA ORAZ ANTAGONIZM IN

VITRO W STOSUNKU DO PATOGENÓW

WYWOŁUJĄCYCH FUZARYJNY UWIĄD W UPRAWACH PSIDIUM GUAJAVA L.

Praca dotyczy analizy losowej amplifikacji polimorfizmów DNA (RAPD)-PCR siedmiu gatunków izolatów grzyba z rodzaju Trichoderma oraz ich antagonizmu in vitro $\mathrm{w}$ stosunku do sprawców uwiądu roślin Psidium guajava L. takich jak grzyby z gatunku Fusarium oxysporum f.sp. psidii oraz Fusarium solani. Sośród 10 testowanych olinukleotydów (OPA1 - OPA10), siedem markerów OPA-1, 3, 5 ,7, 8 i 10 efektywnie różnicowało izolaty grzyba Trichoderma i dawało powtarzalny wzór rozdziału DNA. Całkowitą liczbę 248 pasm otrzymano w przypadku wymienionych markerów wraz z wielkością 61,84\% podobieństwa pomiędzy siedmioma izolatami grzyba Trichoderma. Spośród siedmiu izolatów grzyba Trichoderma najbardziej efektywne przeciwko patogenom Fusarium oxysporum f. sp. psidii i Fusarium solani były gatunki: T. harzianum, T. virens oraz T. viride. Procent inhibicji był najwyższy po bezpośrednim zastosowaniu grzyba Trichoderma spp. zarówno w przypadku patogena F. oxysporum f. sp. psidii jak też F. solani. Gatunki T. virens i T. viride wykazywały silniejsze właściwości hamowania wzrostu obydwóch gatunków Fusarium spp. Izolaty Fusarium charakteryzowała wewnątrz gatunkowa zmienność. 